\title{
Towards Building Sustainable Consumption: A Study of Second-Hand Buying Intentions
}

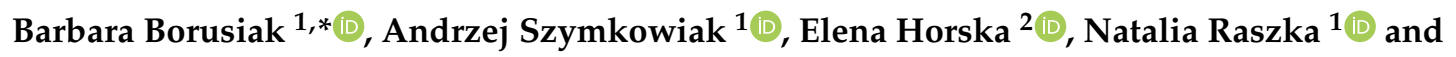 \\ Elżbieta Żelichowska ${ }^{1}$ (D) \\ 1 Department of Commerce and Marketing, Poznan University of Economics and Business, al. \\ Niepodległości 10, 61-875 Poznań, Poland; andrzej.szymkowiak@ue.poznan.pl (A.S.); \\ natalia.raszka@ue.poznan.pl (N.R.); elzbieta.zelichowska@ue.poznan.pl (E.Ż.) \\ 2 Department of Marketing and Trade, Slovak University of Agriculture; Trieda A. Hlinku 2, 94976 Nitra, \\ Slovakia; elena.horska@uniag.sk \\ * Correspondence: barbara.borusiak@ue.poznan.pl
}

Received: 3 December 2019; Accepted: 20 January 2020; Published: 24 January 2020

\begin{abstract}
As the natural resources of the Earth are rapidly depleting, there is an urgent need to encourage people to adopt self-restrictive behaviors, one of which is giving products a second life. The aim of this study is to examine the consumers' intention to buy used products and to visit a second-hand shop using the extended Theory of Planned Behavior (TPB). Additional variables were adopted to give a better insight into the nature of the personal norm. Two variables derived from the Norm Activation Model (NAM) were included in the research model: the awareness of consequences and the ascription of responsibility. In order to collect the data, an online survey was conducted in Poland on 333 participants. SEM was applied for data analysis. The research revealed that the following constructs are positively related to second-hand buying (SHB) intention: the attitude towards the positive impact of SHB on sustainable consumption, and the perceived behavioral control over SHB and the personal norm regarding SHB. Subjective norms regarding SHB are negatively related to SHB intention. An awareness of the consequences of SHB and the ascription of responsibility for the environmental issues are positively related to the personal norm regarding SHB. The intention to buy second-hand products (SHP) is positively related to the intention to visit a second-hand shop.
\end{abstract}

Keywords: sustainable consumption; second-hand buying; consumers' intentions; theory of planned behavior; norm activation model

\section{Introduction}

Climate changes and environment pollution nowadays has become the greatest threat and challenge for humankind [1,2]. The increasing consumption of energy, products, and services is considered to be the main factor determining these changes and hindering sustainability $[3,4]$. Fast fashion changes, as well as short-lived styles, have created a throwaway trend that results in a negative environmental consequence. Solid wastes are constantly growing [5]. By 29 July 2019, the population of the world had used up the natural resources for a whole year, according to the Global Footprint Network, an international sustainability organization that has pioneered the expression ecological footprint. It is Earth Overshoot Day. Its date has moved up two months over the past 20 years to the 29 July this year, the earliest date ever [6].

Therefore, there is an urgent need to make consumers change their patterns of consumption and encourage them to consume in a more sustainable way. Sustainable consumption is defined as a decision-making process taking the consumer's social responsibility into consideration in addition 
to individual preferences concerning a product's attributes [7]. The concept of socially responsible consumption, as well as its measures, has evolved over a period of 40 years. It has expanded from its beginning, during which it related only to environmental concerns, to now including a much wider range of categories [8]. Francois-Lecompte and Roberts [9], as well as Webb, Mohr, and Harris [10], described the socially responsible consumer as "a person basing his or her acquisition, usage and disposition of products on a desire to minimize or eliminate any harmful effects and maximize the long-run beneficial impact on society". According to 3R concept [11] there are three basic types of sustainable consumer behavior: Reduce-Reuse-Recycle, which includes using goods previously used by other people. Second-hand buying (SHB) is the acquisition of used objects through often specific retail formats and places of exchange, both offline and online [12], which results in giving goods a second live. Second-hand products (SHP) are referred to as items that have already been owned and/or used by at least one person prior to the present user $[13,14]$. SHB may result in fewer purchases of new merchandise by consumers, so less resources of all kinds are used and less waste is generated [15].

Some research on SHB motivation and intentions was conducted in the past. The results showed that a set of motives behind SHP has a very complex nature and it includes critical, economic, hedonic [12,16], and fashion reasons [17]. In the studies conducted on Chinese consumers, three main variables influencing the intention behind second-hand clothing use were taken into account: perceived values (hedonic, economic, environmental, and uniqueness), perceived concerns, and perceived descriptive norms. The obtained results varied for four generational cohorts; the youngest respondents (post-1990s) were found to be the most willing to consume second-hand clothing and the same time were the only group whose intention to buy was influenced by perceived economic value [5]. Additionally, some other previous studies showed that economic reasons (price sensitivity and frugality) has a big influence on SHB intention $[12,13,18,19]$. On the other hand, it was found that second-hand buying may not be very rational, not driven by economic reasons but rather an impulse behavior [20]. Very little is known about the intentions behind second-hand buying explained with the use of the Theory of Planned Behavior (TPB) [21]. To the best of our knowledge, there has been no study to build and test the integrative model (including both the TPB and the Norm Activation Model (NAM)) to predict a person's intention to buy a second-hand product, as well as the intention to visit a second-hand shop.

\section{Literature Review}

\subsection{Sustainable Consumption}

Sustainable consumption and production (SCP) is defined as a "holistic approach to minimizing the negative environmental impacts from consumption and production systems while promoting quality of life for all" [22]. It was similarly, but in greater detail, defined by the Oslo Symposium in 1994, as it was said that sustainable consumption and production is about "the use of services and products, which respond to basic needs and improve a quality of life while minimizing the use of natural resources and toxic materials as well as the emissions of waste and pollutants over the life cycle of the service and product so as not to jeopardize the needs of further generations" [23]. Paavola [24] adopted a concise definition of sustainable consumption, referring to it as consumption that entails a reduction of the adverse impact on the environment. He mentioned that people can be less harmful to the environment by modifying their consumption. Lu, Chang, and Chang [25] identified sustainable consumption with the concept of green consumerism. Jaiswal [26] mentioned that terms such as sustainable consumption, ethical consumption, and green consumerism are frequently used interchangeably. Among the aspects on which sustainable consumption focuses are: formulating strategies that support the highest quality of life, the efficient use of natural resources, meeting human needs and also promoting fair social development, technological innovation, and economic competitiveness [27].

The great importance of sustainability results from numerous problems of today's globalized world, with which society is constantly struggling. Among them, such as poverty, climate change, 
environmental pollution, and the finiteness of natural resources are mentioned [28]. According to Zhou et al. [29] many of these problems are the consequences of today's common way of life which is expressed with buying more than one can use. A lot of resources are individually possessed and not shared with others, which means their usage is less effective [30]. To categorize all these problems and aspects, it is worth referring to the dimensions of sustainability. There are three core dimensions of sustainability: environmental, social, and economic [31]. The first refers primarily to the protection of the natural environment and natural resources, the second is related to social and cultural systems, while the last one regards the promotion of the economic well-being of society. All these aspects are related, inter alia, to the effects of consumption for the whole society but also for the individual consumer [32]. Valor and Carrero [33] think that responsible consumption can be perceived as a personal consumer project that focuses on life in a more meaningful way, which may be interpreted as a shift of focus: from buying and possessing products to experiencing benefits coming from products.

\subsection{Second Hand Buying}

Second-hand buying has existed as a type of purchase since the middle of the fourteenth century. At this time, Europe, due to the black plague, was undergoing a deep economic depression, increasing populations, political and social riots, and severe famine [21]. In the 16th century, people started to appreciate rare and valuable fabrics, like silk or Italian cloth, which were also used as a currency. The development of second-hand products trade was observed until the 18th century and the industrial revolution. Then, due to fast-growing production, new products became more available on the market. This influenced the perception of used goods, which lost their meaning and started-because of their lower prices-to be treated as products for the poor [18]. Since the 2000s, second-hand consumption experienced de-stigmatization and renewed popularity [17], and the market of used products is growing [34] and attracting more attention. SHP establish a global business in which export and import plays an important role. For example, the United States of America is recognized as the world's largest exporter of second-hand clothes followed by Germany, the United Kingdom, and the Netherlands. The regions importing the biggest volume of second-hand clothing in the world are: Sub-Sahara Africa, South East Asia, and Eastern Europe [14].

Former studies on second-hand buying were related mainly to clothes and regarded motives of that behavior. At least two group of motivation were distinguished: intrinsic and extrinsic psychological motivation [21]. The former includes elements such as: creating somebody's self-image on authenticity, quality, brand and westerness [35], the expression of moral identity [36], culturally perceived values [37], functional values [38], economic values [39], materialism, which means that people can buy more for less money, and nostalgia [12]. The later factors determining second-hand buying are uniqueness and authenticity [12,40]. Xu et al. [37] found that social norms influence customers' SHB behavior, the process of socialization and a person's positioning in a group.

Among many motivators, environmental concern also appeared. It is observed that, during last decade, consumers started to care more about the environment. Nowadays, they want to have an impact on overproduction and prevent it from having a harmful influence on their living conditions [13]. Researchers showed that students who bought something in a second-hand shop are more conscious about environmental problems [41].

The current study of second-hand buying intentions was conducted in Poland. For the majority of the second half of the 20th century, i.e., in the years 1945-1989, Poland, as all Eastern European countries, was a communist country with a centrally-planned economy, struggling with the predominance of demand over the supply of all consumer goods and practically all products shortages in stores. Second-hand products were transferred within families and groups of friends and were hardly offered on the market; they were offered only by a few consignment shops. After the fall of communism, the number of second-hand shops started to grow rapidly, but buying used products was associated with poverty; shopping for them was assessed as a result of economic necessity, and the use of second-hand products was perceived as an indicator of a low social status. These associations still 
prevent many consumers from entering this type of shop not only in Poland [18] but also in the Czech Republic [19]. What is also significant, Poland is among the high masculine countries (masculinity index of 64 according to Hofstede Insights), which means that, according to the Country Comparison Tool [42], its society is oriented more towards material success than the quality of relationships. Additionally, it is much easier to demonstrate high material status by buying and using new than second-hand products. What is more, Poland has no tradition of charity shops, which could help to elaborate better associations with second-hand products buying. However, after about a thirty-year presence of second-hand shops on the market, the range of people's attitudes towards SHP is wide; from like, interest, and preference to fear and reluctance towards used products. For this reason, the research on SHB was conducted among young people (between 18 and 30 years old) that never experienced communist times or a deep scarcity of goods on the market, so their personal associations of SHP with poverty should be better [19]. The research conducted on Chinese consumers also showed that younger ones (post-1990s) expressed a stronger intention to buy second-hand clothes in comparison with older people [5]. However, other studies on the green consumption attitudes and patterns [43-45] do not support the hypothesis that young people's behavior is more environmentally friendly compared to older individuals. It is explained partly with the lack of necessary resources (like money and/or the influence on decisions in the household). But SHB does not request the aforementioned resources, so these limitations may not work in this case. It is also worth mentioning that the young people's environmental concern and their ability to become change-makers seems to be vital for the future state of the natural environment [46]. Thus, expecting more favorable personal norms and attitudes towards second-hand buying intention, influenced by an awareness of the environmental consequences of SHB, we decided to focus on young Polish consumers.

\subsection{Theoretical Framework and Hypothesis Development}

The Theory of Planned Behavior (TPB) is a well-known concept originating in the field of social psychology, applied for explaining people's behavior connected with choice [47]. Generally speaking, the theory explains the causal relationship between individuals' beliefs, attitudes, intentions, and behaviors. It is an extension of the Theory of Reasoned Action [48], which was made necessary by the original model's limitations in examining behaviors over which individuals have incomplete volitional control. The TPB is accepted as valid and is widely used for examining any type of people's behavior [49]. It was used by numerous researchers for buying and consuming behavior explanation, for example, for predicting healthy eating behaviors [50,51], socially responsible consumption [8], and pro-environmental buying intentions, like consumers' green hotel visit intention [52].

The main assumption of the TPB model is that most people's behavior is under their own control and is rational. The central variable in the TPB is the person's intention to perform a specific behavior. Intention is assumed to aggregate all motivational factors influencing a behavior, which are: attitude towards the behavior, subjective norm, and perceived behavioral control choice [47]. People with stronger intentions tend to engage in a specific behavior since the motivation factors exist in performing the behavior. The theory proposes three determinants that explain a person's behavioral intention: attitude, subjective norms, and perceived behavior control. The last element of the TPB model is the actual behavior, which, according to Ajzen [47], can be predicted from the behavioral intention.

Contrary to the traditional understanding of attitude as a positive or negative assessment of an object, the construct of attitude in the TPB is related to the attitude towards the behavior. It means that the attitude is defined as a positive or negative evaluation of one's performance of the behavior in question $[47,48]$. Due to the aim of this research, attitudes towards the positive impact of SHB on sustainable consumption is assumed to be a significant predictor of SHB intention, which lets us formulate the first hypothesis as follows:

Hypothesis 1 (H1). An attitude toward the positive impact of SHB on sustainable consumption is positively related to SHP purchase intention. 
Subjective norm is the individual's perception of what others think of a specific behavior [47]. So, according to TPB, it is more likely that somebody will buy second-hand products if she or he thinks that her or his friends will expect an/or approve it. It should be stressed that these perceptions may not reflect the real views of others. However, a person's beliefs might affect what she/he thinks about another person's subjective norms [47]. As it was mentioned above, the associations of Poles with second-hand buying are differentiated, but we assume that young Poles are not affected by negative associations with SHB, so the second hypothesis is formulated as follows:

Hypothesis 2 (H2). Subjective norms regarding SHB are positively related to SHP purchase intention.

Perceived behavioral control (PBC), which is another element of TPB, reflects the fact that it is not enough to have a positive attitude to do something. $\mathrm{PBC}$ shows people's perception of their abilities to perform a particular behavior $[47,53,54]$. In case of SHB, people should have the knowledge and the access (in terms of time and location) to that type of merchandise and shopping outlets, so the third hypothesis was formulated as follows:

Hypothesis 3 (H3). Perceived behavioral control over SHB is positively related to SHP purchase intention.

According to Ajzen [47] and Perugini and Bagozzi [55], modifying the TPB model by changing paths and including additional variables in a certain context, in many cases, delivered a better understanding of the model mechanism and increased the prediction power for individuals' intention in that specific context.

In several studies, efforts were made to improve the explanatory power of this theory by including additional variables into the TPB model [56]. In the pro-environmental context, Kaiser and Major [57] pointed out that a model predicting consumers' conservation behavioral intention may contain a moral dimension, which is positively related to consumers' conservation behavioral intention. Second-hand buying, as a form of pro-environmental as well as socially responsible consumption, is a behavior closely related to personal morality and social responsibility.

Former researches, which used the additional elements of TPB for the explanation of pro-environmental intentions, delivered a list of factors. Han and Kim [58] included three additional elements into a model explaining green hotel visit intentions: customer satisfaction, overall image, and frequency of past behavior. Chen and Tung [59] presented a different approach to the TPB model extension. They included two additional variables: environmental concern and perceived moral obligation. Moral obligation is a personal norm by which an individual demonstrates his/her willingness to perform a particular behavior based on his/her personal responsibility or duty. For this reason, in the current research, we adopted the concept of personal norm, derived from the Norm Activation Model (NAM). According to the NAM [60], a person's pro-social and pro-environmental behavior is predicted by three main constructs: the awareness of consequences, the ascription of responsibility, and the personal norm. An awareness of consequences indicates "whether someone is aware of the negative consequences for others or for other things one values when not acting pro-socially" [61]. The ascription of responsibility refers to "feelings of responsibility for the negative consequences of not acting prosocially" [61].

The research model based on the integration of the TPB and the NAM was successfully used for examining the environmentally friendly behavior intentions. Shin et al. [62] used the integrated model for revealing an intention to choose organic menu items and to visit restaurants offering organic menu items. Liu et al. [63] used it for examining individuals' intention to reduce car use. Both teams found out that the proposed model gives a good prediction of the consumers' intentions mentioned above.

The current study research model is supposed to offer a more comprehensive understanding of consumers' intention to buy second-hand product and also to visit a second-hand shop by integrating the TPB and the NAM. The basic premise of the NAM is that the personal norm is a direct determinant 
of pro-social behavior, and behaving in accordance with one's personal norm is self-rewarding. Thanks to acting in line with one's personal norm, people experience positive emotions [64]. In the current research, we also wanted to check how strong the influence of altruistic, pro-social motivation is on SHB intention. For this reason, the following hypotheses will concern the personal norm, the awareness of consequences, the ascription of responsibility, and their relationship with SHP purchase intention. They are formulated as follows:

Hypothesis 4 (H4). Personal norm regarding SHB is positively related to SHP purchase intention.

Hypothesis 5 (H5). Awareness of consequences of SHB for the environment is positively related to a personal norm regarding $S H B$.

Hypothesis 6 (H6). Ascription of responsibility for the environmental issues is positively related to a personal norm regarding $S H B$.

Hypothesis 7 (H7). Awareness of positive consequences of SHB is positively related to an ascription of responsibility for the environmental issues.

The last hypothesis regards the relationship between two logically connected variables: SHP purchase intention and the intention to visit a second-hand shop, which is a next-step intention. The assumption is that people who want to buy something used should be willing to visit a second-hand shop, which is an outlet dedicated for used products acquisition:

Hypothesis 8 (H8). SHP purchase intention is positively related to intention to visit a second-hand shop.

\section{Materials and Methods}

In order to confirm the hypotheses and evaluate the extended TPB model in the context of used product purchases, an online survey measuring the above mentioned constructs was applied. A factor analysis requires a large sample size to construct repeatable and reliable factors. A variety of authors suggest different benchmarks to determine a sufficient sample size for SEM (structural equation modeling). Some authors use benchmarks based on an overall sample size. A common rule of thumb for determining a sufficient sample size is 300 observations [65]. The survey was conducted in three major Polish cities: Poznan, Warsaw, and Katowice between December 2018 and January 2019 on the convenience sample of 333 respondents, $72.9 \%$ of which were female and $27.1 \%$ were male. The mean age of the sample was 24.3 ( $\mathrm{SD}=6.6$ ), $57.9 \%$ assessed their financial situation as good or very good, and $55.6 \%$ lived in cities with more than 500,000 inhabitants.

The questionnaire was divided using section headers and sub-introductions, avoided mixing of items across constructs, and refrained from using negatively-worded items [66]. Respondents were ensured about the confidentiality, anonymity, and voluntariness of the study [66]. Respondents were not rewarded in any way for participating in the study. A survey took about 10-15 min to complete.

Survey questions measuring each of the constructs/variables, the list of which is presented in Table 1, were developed on the extant literature review. The full list of statements used for the variable's measurement is attached in Appendix A.

The questionnaire consisted of two parts: basic questions and a personal questionnaire. All items were measured with a 7-point Likert-type scale, ranging from 1 (strongly disagree) to 7 (strongly agree). All measures were subjected to a confirmatory factor analysis (CFA) to evaluate the convergent and discriminant validity of each construct [67] using $R$ and packages Lavaan and Semtools $[68,69]$. 
Table 1. List of research model variables.

\begin{tabular}{cc}
\hline Variable/Factor/Construct & Abbreviation \\
\hline 1. Attitude toward positive impact of SHB on sustainable consumption. & AT \\
2. Subjective norms regarding SHB. & SN \\
3. Perceived behavioral control over SHB. & PBC \\
4. Personal norm regarding SHB. & PN \\
5. Awareness of consequences of SHB for the environment. & AOC \\
6. Ascription of responsibility for the environmental issues. & AOR \\
7. SHP purchase intention. & PI \\
8. Intention to visit a second-hand shop. & ITV \\
\hline
\end{tabular}

Source: Developed by the authors.

\section{Results and Discussion}

We performed CFA of all correlated factors in the model, which shows a good fit with the data: $\chi^{2} \times(247)=652.71 ; \mathrm{TLI}=0.941, \mathrm{CFI}=0.952 ; \mathrm{RMSEA}=0.07, \mathrm{SRMR}=0.04$. Table 2 shows the measured items with their standardized loadings and all were above the recommended 0.5 [70], (between 0.7 and 0.98). All items were significant at $p<0.001$.

Table 2. Factor loadings.

\begin{tabular}{|c|c|c|c|c|c|c|}
\hline Latent Factor & Indicator & B & SE & $\mathbf{Z}$ & Beta & sig \\
\hline \multirow{3}{*}{$\mathrm{AT}$} & AT1 & 1.26 & 0.06 & 19.88 & 0.88 & $* * *$ \\
\hline & AT2 & 1.31 & 0.07 & 19.87 & 0.88 & $* * *$ \\
\hline & AT3 & 1.30 & 0.07 & 19.38 & 0.86 & $* * *$ \\
\hline \multirow{4}{*}{$\mathrm{SN}$} & SN1 & 1.19 & 0.05 & 22.45 & 0.94 & $* * *$ \\
\hline & SN2 & 1.24 & 0.06 & 22.39 & 0.94 & $* * *$ \\
\hline & SN3 & 1.00 & 0.07 & 14.33 & 0.70 & $* * *$ \\
\hline & SN4 & 1.17 & 0.06 & 18.48 & 0.83 & $* * *$ \\
\hline \multirow{3}{*}{ PBC } & PBC1 & 1.22 & 0.08 & 15.05 & 0.74 & $* * *$ \\
\hline & PBC2 & 1.49 & 0.07 & 20.94 & 0.93 & $* * *$ \\
\hline & PBC3 & 1.23 & 0.08 & 14.96 & 0.73 & $* * *$ \\
\hline \multirow{3}{*}{$\mathrm{PN}$} & PN1 & 1.24 & 0.07 & 19.07 & 0.86 & $* * *$ \\
\hline & PN2 & 1.35 & 0.08 & 16.97 & 0.79 & $* * *$ \\
\hline & PN3 & 1.55 & 0.07 & 20.76 & 0.90 & $* * *$ \\
\hline \multirow{4}{*}{ AOC } & AOC1 & 1.30 & 0.06 & 21.14 & 0.90 & $* * *$ \\
\hline & AOC2 & 1.39 & 0.06 & 23.07 & 0.95 & $* * *$ \\
\hline & AOC3 & 1.45 & 0.07 & 21.25 & 0.90 & $* * *$ \\
\hline & $\mathrm{AOC} 4$ & 1.47 & 0.06 & 22.94 & 0.94 & $* * *$ \\
\hline \multirow{3}{*}{ AOR } & AOR1 & 1.45 & 0.07 & 19.33 & 0.86 & $* * *$ \\
\hline & AOR2 & 1.58 & 0.07 & 21.83 & 0.92 & $* * *$ \\
\hline & AOR3 & 1.54 & 0.07 & 21.97 & 0.93 & $* * *$ \\
\hline \multirow{2}{*}{ PI } & PI1 & 1.48 & 0.07 & 20.27 & 0.89 & $* * *$ \\
\hline & $\mathrm{PI} 2$ & 1.57 & 0.08 & 19.95 & 0.88 & $* * *$ \\
\hline \multirow{3}{*}{ ITV } & ITV1 & 1.86 & 0.08 & 23.15 & 0.95 & $* * *$ \\
\hline & ITV2 & 1.90 & 0.08 & 24.44 & 0.98 & $* * *$ \\
\hline & ITV3 & 1.70 & 0.08 & 20.52 & 0.88 & $* * *$ \\
\hline
\end{tabular}

$p$ value $<0.001,{ }^{* * *}$ Source: Results of own research.

The composite reliability for each scale is higher than 0.7 [71]. The convergent validity, assessed by Average Variance Extracted (AVE), indicates that all constructs have a higher AVE than the benchmark of 0.5 [72]. Table 3 shows the values of Cronbach's alfa, consistency, reliability, and the average variance for each latent variable. 
Table 3. Latent factor correlations.

\begin{tabular}{cccccccccc}
\hline & AT & SN & PBC & PN & AOC & AOR & PI & ITV & Total \\
\hline ALFA & 0.91 & 0.91 & 0.84 & 0.88 & 0.96 & 0.93 & 0.88 & 0.95 & 0.96 \\
CR & 0.91 & 0.91 & 0.84 & 0.89 & 0.96 & 0.93 & 0.88 & 0.96 & 0.98 \\
Ave & 0.76 & 0.72 & 0.65 & 0.72 & 0.85 & 0.82 & 0.79 & 0.88 & 0.78 \\
\hline
\end{tabular}

Source: Results of own research.

The standardized regression path weights show the relative path weight of the factors in the endogenous variables. Chin [73] recommends values greater than 0.3 , however, values greater than 0.2 may be accepted. All the relationships in the proposed model were significant and above the recommended values, except for the subjective norms and purchase intention, which, although significant, was below the recommended value. The model provides a good fit for the data CMIN/df $=2.78, \mathrm{CFI}=0.94, \mathrm{GFI}=0.94, \mathrm{SRMR}=0.06 \mathrm{RMSEA}=0.07, \mathrm{TLI}=0.94$ [74]. Figure 1 illustrates the standardized parameter estimates for the model. Based on the significance of the parameter estimates shown in the model, all but one of the hypotheses (H2 is the exception) are supported (Table 4).

Table 4. Hypotheses testing.

\begin{tabular}{|c|c|c|c|c|c|c|c|c|}
\hline Hypothesis & Factor 1 & & Factor 2 & Path & Sig & ci Lower & ci Upper & Result \\
\hline $\mathrm{H} 1$ & $\mathrm{AT}$ & $\rightarrow$ & PI & 0.17 & $* *$ & 0.06 & 0.28 & Supported \\
\hline $\mathrm{H} 2$ & $\mathrm{SN}$ & $\rightarrow$ & PI & -0.16 & $*$ & -0.28 & -0.03 & Unsupported \\
\hline $\mathrm{H} 3$ & PBC & $\rightarrow$ & PI & 0.29 & $* * *$ & 0.18 & 0.39 & Supported \\
\hline $\mathrm{H} 4$ & $\mathrm{PN}$ & $\rightarrow$ & PI & 0.62 & $* * *$ & 0.46 & 0.78 & Supported \\
\hline H5 & AOC & $\rightarrow$ & $\mathrm{PN}$ & 0.37 & $* * *$ & 0.26 & 0.48 & Supported \\
\hline H6 & AOR & $\rightarrow$ & $\mathrm{PN}$ & 0.26 & $* * *$ & 0.17 & 0.36 & Supported \\
\hline H7 & AOC & $\rightarrow$ & AOR & 0.67 & $* * *$ & 0.60 & 0.74 & Supported \\
\hline H8 & PI & $\rightarrow$ & ITV & 0.82 & $* * *$ & 0.77 & 0.86 & Supported \\
\hline
\end{tabular}

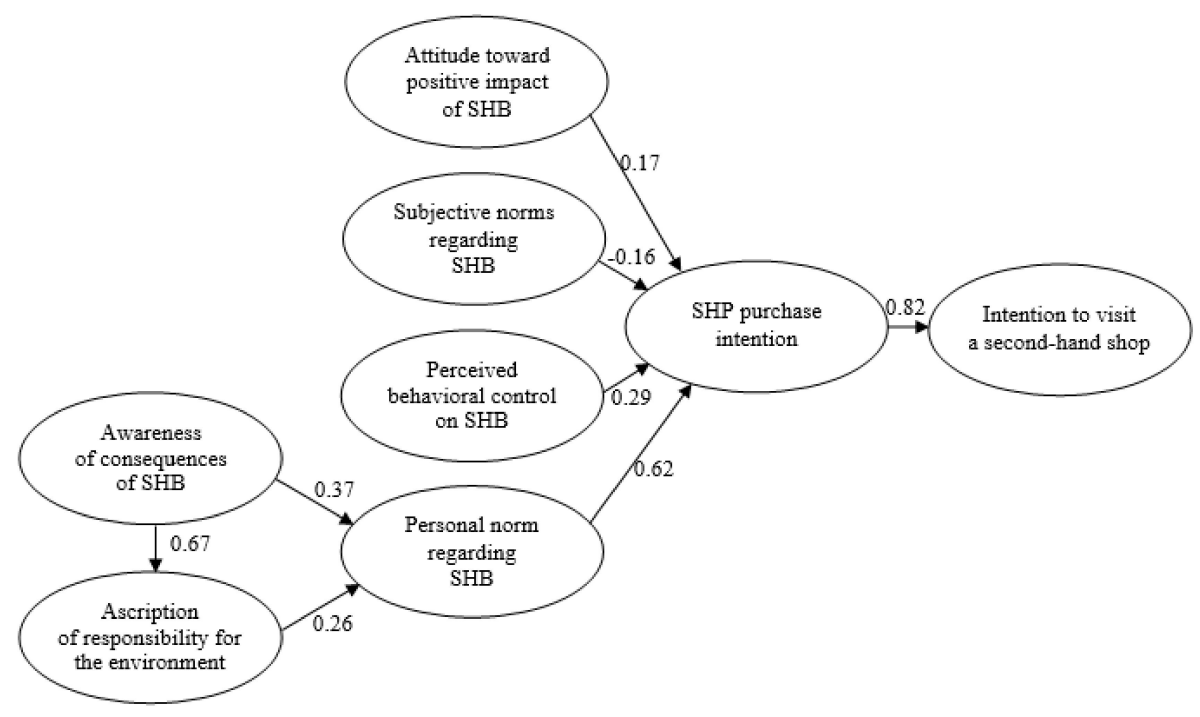

Figure 1. Standardized parameter estimates for the research model.

The results of the present study confirm the utility of the integrated approach using both the Theory of Planned Behavior and the Norm Activation Model as a framework for understanding SHP purchase intentions and the intentions towards visiting a second-hand shop. Attitudes, subjective norms, perceived behavioral control, and the personal norm accounted for a large proportion of the variance in the intentions to buy used products, and these intentions afforded good prediction of the intentions behind visiting a second-hand shop. Structural equation analyses revealed a good fit 
between the adopted theoretical framework based on both the TPB model and the Norm Activation Model. Adjusted goodness of the fit index at the level 0.94 indicates that the intention to buy used products and the intention to visit a store or e-store with used products can be explained by a combination of variables applied in the study. However, it should be pointed out that, according to the adopted hypotheses, not all independent variables have a positive influence on the dependent variables. The outcomes demonstrate that the attitude towards second-hand buying is positively related to SHP purchase intention $(\beta=0.17, p<0.01)$ as well as perceived behavioral control $(\beta=0.29$, $p<0.001)$, and the personal norm $(\beta=0.62, p<0.001)$. The personal norm is influenced by both the awareness of consequences of SHB for the environment $(\beta=0.37, p<0.001)$ and the ascription of the responsibility for the environment $(\beta=0.26, p<0.001)$. The awareness of consequences is positively related to the ascription of responsibility $(\beta=0.67, p<0.001)$. We also found out that subjective norms concerning SHB are negatively related to SHB intention $(\beta=-0.16, p<0.05)$. Looking at the possible reasons behind this, it must be emphasized that social norms refer to the perceived social pressure to get involved in a specific behavior. Cialdini [75] proposed to distinguish two types of norms: injunctive, which refers to what is expected to be done (included in the TPB model and applied in the current study), and descriptive, which refers to what people actually do (not included in the TPB model). They are driven by different motives: in the case of injunctive norms, people obey the norm as it is based on the social evaluation and they are afraid of being excluded from the group when they do not behave in line with a norm. Descriptive norms facilitate behavior by their informational role; people learn what is appropriate thanks to them. It is like delivering a message: if so many people do it, it is very likely that it is smart to do it [64]. The results we got in the current study show that the injunctive social norm works against SHB, which is very likely connected to the bad associations with SHB that still exist in post-communist countries in general. For example, in the qualitative studies conducted in Poland [76] and in the Czech Republic [19], people commenting on second-hand shops mentioned that these shops and their merchandise have an unpleasant smell. So SHB is not a desired behavior but it seems to be widely accepted, especially in the case of specific products. The majority of cars bought in Poland every year have been used by someone else before and this is a widely accepted, even recognized as smart behavior (due to the steep drop in price in the case of cars that have been bought new and resold).

This means that even young consumers in Poland, which have never experienced a shortage of merchandise on the market, are affected by negative associations with SHB, so they do not assess SHB as a behavior, which is expected or supported by others who are important to them. That result is different to many previous studies results concerning other sustainable products purchase intentions: green food [77], green hotels [59], or organic menu items [62]. Trying to find the reasons for this discrepancy, we should take into account that, contrary to the above mentioned pro-environmental behavior, SHB may carry higher social risks (face saving concerns), which may especially influence the injunctive social norm [78] in countries where the perception of the material status of an individual is quite important (as in Poland).

On the other hand, the current research shows the high influence of pro-social motivation expressed by the personal norm on SHB intention, driven by both an awareness of consequences and the ascription of responsibility for the environment, which is consistent with the previous studies [62].

\section{Conclusions and Implications}

Due to the threat of the climate disaster, it is vital to understand any aspect of customers' behaviors related to sustainable consumption in order to promote the desirable patterns of behavior. Second-hand buying is a kind of activity supporting that type of consumption. The proposed research model was an attempt to provide a more comprehensive understanding of second-hand buying intentions. By integrating the TPB and the NAM, this study demonstrated that the model is applicable to predict the consumers' intention to choose second-hand products and to visit second-hand shops. The study reveals that all considered independent variables are significantly related to the dependent variables. 
Both self-interest motive and prosocial motive significantly influence a customer's intention regarding pro-environmental behavior, which is consistent with the previous studies $[62,79]$.

Another important conclusion from the current study comes from NAM usage to explain SHB intention. It turned out that the personal norm plays a very important role in explaining SHB intention, much more important than other variables. So, despite the fact that subjective norms counteract the purchase of SHP, personal norm expresses support for this activity. This is a very promising result from the point of view of practical implications, but further research should be conducted on the more representative sample. The study also showed that both an awareness of consequences and the ascription of responsibility directly influences the personal norm, which is consistent with some former studies [62] but opposite to another [80]. It may be explained with the sample of the research: young people are usually more aware of sustainable issues [41] and are more open-minded. But it also indicates the need for further research, which should include the whole range of the population.

The results of the study are also important from the point of view of the practical implications of the conclusions. If the subjective norms regarding SHB express reluctance and even the fear and avoidance of SHB, it is necessary to apply activities convincing people that SHB may deliver them a lot of advantages, such as sustainability protection, unique and authentic products, economic profits connected with the option to buy at low prices, hunting pleasure, and even ethical advantages (for example, when shopping in a charity store) by education. However, possibly the best option for implementing this recommendation would be to show that second-hand buying is popular and practiced by many, including celebrities and influential bloggers, as it was done before in many countries [13].

There were several limitations in this study. The data were collected by a self-reporting technique, which may bias the results due to the social desirability effect. The other one is connected with the sample, which is not representative for young customers. A total of $72.9 \%$ of answers were delivered by women and only $27.1 \%$ by men, which does not reflect the real gender structure. However, it fits the results of the previous studies, showing that women are more likely to be involved in second-hand activities, including buying [15]. The majority of respondents live in big cities, whereas only $19.9 \%$ of the Polish population lived in the cities with over 200,000 inhabitants in 2018 (due to the official statistics). As the convenience sample was used, it is possible that the survey attracted more people that buy second-hand products and have a more positive attitude towards SHP in general. What is more, neither the type of product nor the alternative retail format (store-based or on-line) was taken into account in the study. So, it would be very valuable to test the research model for specified products (for example, used cars, used pieces of furniture, second-hand high-fashion clothes, or used electronics) and various retail formats, like an online second-hand share platform, vintage shop, pawn shop, charity/thrift store, and flea market.

It would also be interesting to find out how the intentions toward SHB may be explained in other countries of Eastern and Southern Europe-countries that have, on the one hand, experienced a great scarcity of goods; and a huge supply of imported second-hand products on the other-but also in those countries in which the society cannot remember any shortage of merchandise on the market. Some studies on environmentally-motivated consumption reduction was conducted in the past on a big international scale-in 30 European countries. It was found that in countries with predominantly materialist values there is less likely to be a positive relationship between environmental knowledge and pro-environmental attitudes $[44,45]$. However, no studies before were conducted on SHP behavior on a comparable scale. And it is quite a special manifestation of consumption reduction that was not taken into account among environmentally-motivated consumption reduction [44] or climate mitigating actions [45]. SHP may be recognized as an activity negatively influencing perceived social status $[5,18,19]$ so further research on attitudes, social norms (both injunctive and descriptive), intentions, and SHP behavior, depending on the culture of the country, is necessary in order to deepen the knowledge of other aspects of self-limiting behavior and to design campaigns that effectively promote desirable, pro-environmental behavior. 
Author Contributions: Conceptualization: B.B.; methodology: B.B., A.S., E.H.; software: A.S.; formal analysis: A.S.; investigation: B.B., E.H.; resources: B.B., A.S., E.H., N.R., E.Ż.; writing-original draft preparation: B.B., A.S., E.Ż.; writing—review and editing: B.B., E.H., E.Ż.; visualization: N.R., E.Ż.; supervision: B.B.; project administration: B.B. All authors have read and agreed to the published version of the manuscript.

Funding: This research received no external funding.

Conflicts of Interest: The authors declare no conflict of interest.

\section{Appendix A}

Table A1. Constructs (variables) and items used in an online questionnaire.

\begin{tabular}{|c|c|c|}
\hline CONSTRUCT & ITEMS & SOURCE \\
\hline \multirow{3}{*}{$\begin{array}{l}\text { Attitude toward positive impact of } \\
\text { SHB on sustainable consumption } \\
\text { (AT) }\end{array}$} & $\begin{array}{l}\text { AT1. I believe that second-hand buying by me will help in reducing } \\
\text { pollution and also help in improving the state of the environment. }\end{array}$ & \multirow{3}{*}{$\begin{array}{l}\text { (Valle, Rebelo, Reis, } \\
\text { \& Menezes, 2016) [81] }\end{array}$} \\
\hline & $\begin{array}{l}\text { AT2. I believe that second-hand buying by me will help in reducing } \\
\text { wasteful usage of natural resources. }\end{array}$ & \\
\hline & $\begin{array}{l}\text { AT3. I believe that second-hand buying by me will help in natural } \\
\text { resources protection. }\end{array}$ & \\
\hline \multirow{4}{*}{$\begin{array}{l}\text { Subjective norms regarding } \mathrm{SHB} \\
\qquad(\mathrm{SN})\end{array}$} & SN1. My friends expect me to buy second hand products. & \multirow{4}{*}{$\begin{array}{l}\text { (Joshi \& Rahman, 2017) [82] } \\
\text { (Vermeir \& Verbeke, 2008) [7] }\end{array}$} \\
\hline & SN2. My family expects me to buy second hand products. & \\
\hline & SN3. Society expects me to buy second hand products. & \\
\hline & $\begin{array}{l}\text { SN4. Most people who are important to me think that I should buy } \\
\text { a second-hand item when I have to buy something. }\end{array}$ & \\
\hline \multirow{3}{*}{$\begin{array}{c}\text { Perceived behavioural control } \\
\text { over SHB } \\
(\mathrm{PBC})\end{array}$} & PBC1. I know where I can buy second-hand products. & \multirow{3}{*}{ (Shin et al. 2018) [62] } \\
\hline & PBC2. I am capable of buying second-hand products. & \\
\hline & $\begin{array}{l}\text { PBC3. I have enough time to choose a second hand product when I } \\
\text { have to buy something. }\end{array}$ & \\
\hline \multirow{3}{*}{$\begin{array}{l}\text { Personal norm } \\
\text { regarding SHB } \\
\quad(\mathrm{PN})\end{array}$} & $\begin{array}{l}\text { PN1. I believe I have a moral obligation to choose a second-hand } \\
\text { product when I have to buy something. }\end{array}$ & \multirow{3}{*}{ (Shin et al. 2018) [62] } \\
\hline & $\begin{array}{l}\text { PN2.Choosing a second-hand product is consistent with my moral } \\
\text { principles. }\end{array}$ & \\
\hline & $\begin{array}{l}\text { PN3. My personal values encourage me to choose a second-hand } \\
\text { product when I have to buy something. }\end{array}$ & \\
\hline \multirow{4}{*}{$\begin{array}{l}\text { Awareness of consequences of SHB } \\
\text { for the environment } \\
\text { (AOC) }\end{array}$} & $\begin{array}{l}\text { AOC1. I believe that second-hand buying can slow down the tempo } \\
\text { of exhaustion of natural resources. }\end{array}$ & \multirow{4}{*}{ (Shin et al. 2018) [62] } \\
\hline & $\begin{array}{l}\text { AOC2. The second-hand sector can possibly have environmental } \\
\text { impact on the environment. }\end{array}$ & \\
\hline & AOC3. The second-hand sector can cause the climate change. & \\
\hline & $\begin{array}{l}\text { AOC4. I think that second- hand buying helps minimize } \\
\text { environmental degradations. }\end{array}$ & \\
\hline \multirow{3}{*}{$\begin{array}{l}\text { Ascription of responsibility for } \\
\text { environmental issues (AOR) }\end{array}$} & $\begin{array}{l}\text { AOR1. Every customer should feel partly responsible for } \\
\text { environmental problems caused by the industry. }\end{array}$ & \multirow{3}{*}{ (Shin et al. 2018) [62] } \\
\hline & $\begin{array}{l}\text { AOR2. Every customer has to take responsibility for the } \\
\text { environmental problems caused by the industry. }\end{array}$ & \\
\hline & $\begin{array}{l}\text { AOR3. I think that every customer is partly responsible for the } \\
\text { environmental deteriorations caused by the industry. }\end{array}$ & \\
\hline \multirow[t]{2}{*}{ SHP purchase intention (PI) } & $\begin{array}{l}\text { PI1. It is very likely that I will buy a second-hand product in the } \\
\text { future. }\end{array}$ & \multirow[t]{2}{*}{ (Putrevu \& Lord, 1994) [83] } \\
\hline & PI2. Certainly I will buy a second-hand product. & \\
\hline \multirow{3}{*}{$\begin{array}{l}\text { Intention to visit } \\
\text { a second-hand shop } \\
\text { (ITV) }\end{array}$} & $\begin{array}{l}\text { ITV1. I plan to visit a shop (brick\&mortar or e-commerce) with } \\
\text { second-hand products. }\end{array}$ & \multirow{3}{*}{ (Shin et al. 2018) [62] } \\
\hline & $\begin{array}{l}\text { ITV2. I intend to visit a shop (brick\&mortar or e-commerce) with } \\
\text { second-hand products. }\end{array}$ & \\
\hline & $\begin{array}{l}\text { ITV3. I will do my best to visit a second-hand shop (brick\&mortar } \\
\text { or e-commerce) in the future. }\end{array}$ & \\
\hline
\end{tabular}




\section{References}

1. Chua, K.B.; Quoquab, F.; Mohammad, J.; Basiruddin, R. The Mediating Role of New Ecological Paradigm between Value Orientations and Pro-Environmental Personal Norm in the Agricultural Context. Asia Pac. J. Mark. Logist. 2016, 28, 323-349. [CrossRef]

2. Yoon, S.W.; Yoon, C.-H. On the impossibility of sustainable growth in a manufacturing based economy. Economic Research-Ekonomska Istraživanja 2018, 31, 1526-1538. [CrossRef]

3. Fischer, D.; Böhme, T.; Geiger, S.M. Measuring young consumers' sustainable consumption behavior: Development and validation of the YCSCB scale. Young Consum. Insight Ideas Responsib. Mark. 2017, 18, 312-326. [CrossRef]

4. Khoshnevis Yazdi, S.; Dariani, A.G. CO2 emissions, urbanisation and economic growth: Evidence from Asian countries. Economic Research-Ekonomska Istraživanja 2019, 32, 510-530. [CrossRef]

5. Liang, J.; $\mathrm{Xu}, \mathrm{Y}$. Second-hand clothing consumption: A generational cohort analysis of the Chinese market. Int. J. Consum. Stud. 2018, 42, 120-130. [CrossRef]

6. Global Footprint Network. Advancing the Science of Sustainability. Available online: https://www. fotprintnetwork.org (accessed on 28 November 2019).

7. Vermeir, I.; Verbeke, W. Sustainable food consumption among young adults in Belgium: Theory of planned behaviour and the role of confidence and values. Ecol. Econ. 2008, 64, 542-553. [CrossRef]

8. Prendergast, G.P.; Tsang, A.S.L. Explaining socially responsible consumption. J. Consum. Mark. 2019, 36, 146-154. [CrossRef]

9. Francois-Lecompte, A.; Roberts, J.A. Developing a measure of socially responsible consumption in France. Mark. Manag. J. 2006, 16, 50-66.

10. Webb, D.J.; Mohr, L.A.; Harris, K.E. A re-examination of socially responsible consumption and its measurement. J. Bus. Res. 2008, 61, 91-98. [CrossRef]

11. Palmeira, M.; Musso, F. 3Rs of Sustainability Values for Retailing Customers as Factors of Influence on Consumer Behavior. In Handbook of Research on Retailing Techniques for Optimal Consumer Engagement and Experiences; Palmeira, M., Musso, F., Eds.; IGI Global: Hershey, PA, USA, 2020; pp. 421-444.

12. Roux, D.; Guiot, D. Measuring second-hand shopping motives, antecedents and consequences. Recherche et Applications en Marketing 2008, 23, 63-94. [CrossRef]

13. Cervellon, M.-C.; Carey, L.; Harms, T. Something old, something used: Determinants of women's purchase of vintage fashion vs second-hand fashion. Int. J. Retail. Distrib. Manag. 2012, 40, 956-974. [CrossRef]

14. Chipambwa, W.; Sithole, L.; Chisosa, D.F. Consumer perceptions towards second-hand undergarments in Zimbabwe: A case of Harare urban dwellers. Int. J. Fash. Des. Technol. Educ. 2016, 9, 176-182. [CrossRef]

15. Lane, R.; Horne, R.; Bicknell, J. Routes of Reuse of Second-hand Goods in Melbourne Households. Aust. Geogr. 2009, 40, 151-168. [CrossRef]

16. Guiot, D.; Roux, D. A Second-Hand Shoppers' Motivation Scale: Antecedents, Consequences, and Implications for Retailers. J. Retail. 2010, 86, 383-399. [CrossRef]

17. Ferraro, C.; Sands, S.; Brace-Govan, J. The role of fashionability in second-hand shopping motivations. J. Retail. Consum. Serv. 2016, 32, 262-268. [CrossRef]

18. Rybowska, A. Consumers Behavior in the Second Hand Market. Marketing i Zarzadzanie 2017, 48, 95-104. [CrossRef]

19. Rulikova, M. "I would never wear those old clodhoppers!": Age differences and used clothing consumption in the Czech Republic. J. Consum. Cult. 2019. Available online: https://journals.sagepub.com/doi/full/10. 1177/1469540519891274 (accessed on 2 January 2020).

20. Parguel, B.; Lunardo, R.; Benoît-Moreau, F. Sustainability of the sharing economy in question: When second-hand peer-to-peer platforms stimulate indulgent consumption. Technol. Forecast. Soc. Chang. 2017, 125, 48-57. [CrossRef]

21. Herjanto, H.; Scheller-Sampson, J.; Erickson, E. The increasing phenomenon of second-hand clothes purchase: Insights from the literature. Jurnal Manajemen Dan Kewirausahaan 2016, 18, 1-15.

22. United Nations Environment Programme. Paving the Way for Sustainable Consumption and Production the Marrakech Process Progress Report. 2011. Available online: https://sustainabledevelopment.un.org/content/ documents/947Paving_the_way_final.pdf (accessed on 30 January 2019). 
23. Sustainable Development Goals. Knowledge Platform. Sustainable Consumption and Production. Available online: https://sustainabledevelopment.un.org/topics/sustainableconsumptionandproduction (accessed on 28 November 2019).

24. Paavola, J. Towards Sustainable Consumption: Economics and Ethical Concerns for the Environment in Consumer Choices. Rev. Soc. Econ. 2001, 59, 227-248. [CrossRef]

25. Lu, L.-C.; Chang, H.-H.; Chang, A. Consumer Personality and Green Buying Intention. The Mediate Role of Consumer Ethical Beliefs. J. Bus. Ethics 2015, 127, 205-219. [CrossRef]

26. Jaiswal, N. Green products. Availability, awareness and preference of use by the families. Indian J. Environ. Educ. 2012, 12, 21-25.

27. Tukker, A.; Cohen, M.J.; Zoysa, U.; Hertwich, E.; Hofstetter, P.; Inaba, A.; Lorek, S.; Stø, E. The Oslo Declaration on Sustainable Consumption. J. Ind. Ecol. 2006, 10, 9-14. [CrossRef]

28. Buerke, A.; Straatmann, T.; Lin-Hi, N.; Müller, K. Consumer awareness and sustainability-focused value orientation as motivating factors of responsible consumer behavior. Rev. Manag. Sci. 2017, 11, 959-991. [CrossRef]

29. Zhou, Y.; Thøgersen, J.; Ruan, Y.; Huang, G. The moderating role of human values in planned behavior: The case of Chinese consumers intention to buy organic food. J. Consum. Mark. 2013, 30, 335-344. [CrossRef]

30. Laurenti, R.; Singh, J.; Cotrim, J.M.; Toni, M.; Sinha, R. Characterizing the Sharing Economy State of the Research: A Systematic Map. Sustainability 2019, 11, 5729. [CrossRef]

31. Phipps, M.; Ozanne, L.K.; Luchs, M.G.; Subrahmanyan, S.; Kapitan, S.; Catlin, J.R.; Gau, R.; Walker Naylor, R.; Rose, R.L.; Simpson, B.; et al. Understanding the inherent complexity of sustainable consumption: A social cognitive framework. J. Bus. Res. 2013, 66, 1227-1234. [CrossRef]

32. Brinkmann, J.; Peattie, K. Consumer Ethics Research: Reframing the Debate about Consumption for Good. Electronic J. Bus. Ethics Organ. Stud. 2008, 13, 22-31.

33. Valor, C.; Carrero, I. Viewing Responsible Consumption as a Personal Project. Psychol. Mark. 2014, 31, 1110-1121. [CrossRef]

34. Shulman, J.D.; Coughlan, A.T. Used goods, not used bads: Profitable secondary market sales for a durable goods channel. Quant. Mark. Econ. 2007, 5, 191-210. [CrossRef]

35. Na'Amneh, M.M.; Al Husban, A.K. Identity in old clothes: The socio-cultural dynamics of second-hand clothing in Irbid, Jordan. Soc. Identities J. Stud. Race Nation Cult. 2012, 18, 609-621. [CrossRef]

36. Brace-Govan, J.; Binay, I. Consumption of disposed goods for moral identities: A nexus of organization, place, things and consumers. J. Consum. Behav. 2010, 9, 69-82. [CrossRef]

37. Xu, Y.; Chen, Y.; Burman, R.; Zhao, H. Second-hand clothing consumption: A cross-cultural comparison between American and Chinese young consumers. Int. J. Consum. Stud. 2014, 38, 670-677. [CrossRef]

38. Isla, V.L. Investigating second-hand fashion trade and consumption in the Philippines: Expanding existing discourses. J. Consum. Cult. 2013, 13, 221-240. [CrossRef]

39. Jägel, T.; Keeling, K.A.; Reppel, A.; Gruber, T. Individual values and motivational complexities in ethical clothing consumption: A means-end approach. J. Mark. Manag. 2012, 28, 373-396. [CrossRef]

40. Hansen, K.T. Second hand clothing encounters in Zambia: Global discourses, western commodities and local history. J. Int. Afr. Inst. 1999, 69, 343-365. [CrossRef]

41. Yan, R.-N.; Bae, S.Y.; Xu, H. Second-hand clothing shopping among college students: The role of psychographic characteristics. Young Consum. Insight Ideas Responsib. Mark. 2015, 16, 85-98. [CrossRef]

42. Hofstede Insights. Country Comparison. Available online: https://www.hofstede-insights.com/ countrycomparison/ (accessed on 28 November 2019).

43. Diamantopoulos, A.; Schlegelmilch, B.B.; Sinkovics, R.R.; Bohlen, G.M. Can socio-demographics still play a role in profiling green consumers? A review of the evidence and an empirical investigation. J. Bus. Res. 2003, 56, 465-480. [CrossRef]

44. Ortega Egea, J.M.; García-de-Frutos, N. Toward Consumption Reduction: An Environmentally Motivated Perspective. Psychol. Mark. 2013, 30, 660-675. [CrossRef]

45. Ortega-Egea, J.M.; García-de-Frutos, N.; Antolín-López, R. Why Do Some People Do “More” to Mitigate Climate Change than Others? Exploring Heterogeneity in Psycho-Social Associations. PLoS ONE 2014, 9, e106645. [CrossRef]

46. Boca, G.D.; Saraçlı, S. Environmental Education and Student's Perception, for Sustainability. Sustainability 2019, 11, 1553. [CrossRef] 
47. Ajzen, I. The Theory of Planned Behavior. Organ. Behav. Human Decis. Proc. 1991, 50, 179-211. [CrossRef]

48. Ajzen, I.; Fishbein, M. Understanding Attitudes and Predicting Social Behavior; Prentice-Hall: Englewood Cliffs, NY, USA, 1980.

49. Yuzhanin, S.; Fisher, D. The efficacy of the theory of planned behavior for predicting intentions to choose a travel destination: A review. Tour. Rev. 2016, 71, 135-147. [CrossRef]

50. Brouwer, A.M.; Mosack, K.E. Expanding the theory of planned behavior to predict healthy eating behaviors. Nutr. Food Sci. 2015, 45, 39-53. [CrossRef]

51. Close, M.A.; Lytle, L.A.; Chen, D.-G.; Viera, A.J. Using the theory of planned behavior to explain intention to eat a healthful diet among Southeastern United States office workers. Nutr. Food Sci. 2018, 48, 365-374. [CrossRef]

52. Verma, V.K.; Chandra, B. An application of theory of planned behavior to predict young Indian consumers' green hotel visit intention. J. Clean. Prod. 2018, 172, 1152-1162. [CrossRef]

53. Armitage, C.J.; Conner, M. Efficacy of the Theory of Planned Behaviour: A meta-analytic review. Br. J. Soc. Psychol. 2001, 40, 471-499. [CrossRef] [PubMed]

54. Bagozzi, R.P. The Self-Regulation of Attitudes, Intentions, and Behavior. Soc. Psychol. Q. 1992, 55, $178-204$. [CrossRef]

55. Perugini, M.; Bagozzi, R.P. The role of desires and anticipated emotions in goal-directed behaviours: Broadening and deepening the theory of planned behaviour. Br. J. Soc. Psychol. 2001, 40, 79-98. [CrossRef]

56. Kaiser, F.G.; Scheuthle, H. Two challenges to a moral extension of the theory of planned behavior: Moral norms and just world beliefs in conservationism. Personal. Individ. Differ. 2003, 35, 1033-1048. [CrossRef]

57. Kaiser, C.R.; Major, B. A Social Psychological Perspective on Perceiving and Reporting Discrimination. Law Soc. Inq. 2006, 31, 801-830. [CrossRef]

58. Han, H.; Kim, Y. An investigation of green hotel customers' decision formation: Developing an extended model of the theory of planned behavior. Int. J. Hosp. Manag. 2010, 29, 659-668. [CrossRef]

59. Chen, M.-F.; Tung, P.-J. Developing an extended Theory of Planned Behavior model to predict consumers' intention to visit green hotels. Int. J. Hosp. Manag. 2014, 36, 221-230. [CrossRef]

60. Schwartz, S.H. Normative Influences on Altruism. In Advances in Experimental Social Psychology; Berkowitz, L., Ed.; Academic Press: New York, NY, USA, 1977; Volume 10, pp. 221-279.

61. De Groot, J.I.M.; Steg, L. Morality and prosocial behavior: The role of awareness, responsibility and norms in the norm activation model. J. Soc. Psychol. 2009, 149, 425-449. [CrossRef] [PubMed]

62. Shin, Y.H.; Im, J.; Jung, S.E.; Severt, K. The theory of planned behavior and the norm activation model approach to consumer behavior regarding organic menus. Int. J. Hosp. Manag. 2018, 69, 21-29. [CrossRef]

63. Liu, Y.; Sheng, H.; Mundorf, N.; Redding, C.; Ye, Y. Integrating Norm Activation Model and Theory of Planned Behavior to Understand Sustainable Transport Behavior: Evidence from China. Int. J. Environ. Res. Public Health 2017, 14, 1593. [CrossRef]

64. Bamberg, S. Understanding and Promoting Bicycle Use-Insights from Psychological Research. In Transport and Sustainability, Cycling and Sustainability; Parkin, J., Ed.; Emerald Group Publishing Limited: London, UK, 2012; Volume 1, pp. 219-246.

65. Tabachnick, B.G.; Fidell, L.S. Using Multivariate Statistics, 6th ed.; Pearson Education: Boston, MA, USA, 2013.

66. Podsakoff, P.M.; MacKenzie, S.B.; Lee, J.-Y.; Podsakoff, N.P. Common method biases in behavioral research: A critical review of the literature and recommended remedies. J. Appl. Psychol. 2003, 88, 879-903. [CrossRef]

67. Bagozzi, R.P.; Yi, Y. Specification, evaluation, and interpretation of structural equation models. J. Acad. Mark. Sci. 2012, 40, 8-34. [CrossRef]

68. Li, H.; Handsaker, B.; Wysoker, A.; Fennell, T.; Ruan, J.; Homer, N.; Marth, G.; Abecasis, G.; Durbin, R. The Sequence Alignment/Map format and SAMtools. Bioinformatics 2009, 25, 2078-2079. [CrossRef]

69. Rosseel, Y. lavaan: An R Package for Structural Equation Modeling. J. Statistical Software 2012, 48, 1-36. [CrossRef]

70. Hair, J.F.; Black, W.C.; Babin, B.J.; Anderson, R.E. Multivariate Data Analysis, 7th ed.; Pearson: Harlow, UK, 2009.

71. Fornell, C.; Larcker, D.F. Evaluating Structural Equation Models with Unobservable Variables and Measurement Error. J. Mark. Res. 1981, 18, 39-50. [CrossRef]

72. Bagozzi, R.P.; Yi, Y. On the evaluation of structural equation models. J. Acad. Mark. Sci. 1988, 16, 74-94. [CrossRef] 
73. Chin, W.W. The Partial Least Squares Approach to Structural Equation Modeling. In Modern Methods for Business Research; Marcoulides, G.A., Ed.; Lawrence Erlbaum Associates Publishers: Mahwah, NY, USA, 1998; pp. 295-336.

74. Sharma, S.; Mukherjee, S.; Kumar, A.; Dillon, W.R. A simulation study to investigate the use of cutoff values for assessing model fit in covariance structure models. J. Bus. Res. 2005, 58, 935-943. [CrossRef]

75. Cialdini, R. Descriptive Social Norms as Underappreciated Sources of Social Control. Psychometrika 2007, 72, 263-268. [CrossRef]

76. Borusiak, B.; Paluchova, J. Business with a Mission: The Motives Behind Engagement in Charity Retailing. Handel Wewn. 2018, 6, 7-17.

77. Ham, M.; Jeger, M.; Frajman Ivković, A. The role of subjective norms in forming the intention to purchase green food. Econ. Res.-Ekon. Istraž. 2015, 28, 738-748. [CrossRef]

78. Wenger, E. Communities of practice: Learning as a social system. Syst. Think. 1998, 9, 2-3. [CrossRef]

79. Han, H.; Meng, B.; Kim, W. Bike-traveling as a growing phenomenon: Role of attributes, value, satisfaction, desire, and gender in developing loyalty. Tour. Manag. 2017, 59, 91-103. [CrossRef]

80. Han, H. The norm activation model and theory-broadening: Individuals' decision-making on environmentally-responsible convention attendance. J. Environ. Psychol. 2014, 40, 462-471. [CrossRef]

81. Valle, P.O.D.; Rebelo, E.; Reis, E.; Menezes, J. Combining Behavioral Theories to Predict Recycling Involvement. Environ. Behav. 2016, 37, 364-396. [CrossRef]

82. Joshi, Y.; Rahman, Z. Investigating the determinants of consumers' sustainable purchase behaviour. Sustain. Prod. Consum. 2017, 10, 110-120. [CrossRef]

83. Putrevu, S.; Lord, K.R. Comparative and Noncomparative Advertising: Attitudinal Effects under Cognitive and Affective Involvement Conditions. J. Advert. 1994, 23, 77-91. [CrossRef]

(C) 2020 by the authors. Licensee MDPI, Basel, Switzerland. This article is an open access article distributed under the terms and conditions of the Creative Commons Attribution (CC BY) license (http://creativecommons.org/licenses/by/4.0/). 